\section{生育と $\mathrm{pH}$}

(微生物除草剤)

\section{ザントモナス キャンペストリス}

\section{1. 薬剤の名称}

1) 一般名：ザントモナス キャンペストリス

2 ) 学名: Xanthomonas campestris pv. poae

$$
\begin{aligned}
& \text { (ザントスモナス キャンペストリス } \\
& \text { パソバー ポアエ) } \\
& \text { スズメノカタビラ萎调細菌病 }
\end{aligned}
$$

3 ) 略名 (試験名)：JTH-101

4 ) 商品名：キャンペリコ®液剤

2. 物理化学的性状

1) 微生物の形態 グラム陰性の運動性を有する桿菌

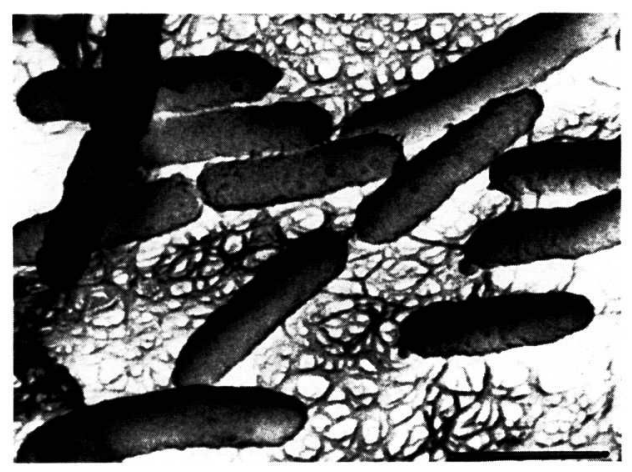

$(1 \mu \mathrm{m})$

写真 1 ザントモナス キャンペストリス (電子顕微鏡写真)

2 ) 微生物の分類学上の位置

界: Procaryotae

門：Gracilicutes

綱: Scotobacteria

科: Pseudomonadaceae

属: Xanthomonas

種: campestris

病原型 (pathovar) : poae

株 : P-482

3 ) 微生物の生物学的性質

生育と温度

生育温度範囲 $5.8 \sim 38^{\circ} \mathrm{C}$

生育最適温度 $\quad 30 \sim 31^{\circ} \mathrm{C}$
生育初発 $\mathrm{pH}$ 範囲 $5.5 \sim 9$

生育最適初発 $\mathrm{pH} \quad 6 \sim 6.5$

4 ) 性状：黄色水溶性懸濁液体

\section{3. 作用機構及び作用特性}

1) 本剂はスズメノカタビラの植物病原細菌の宿 主特異性を利用しているので, 活性の範囲はスズメ ノカタビラのみに選択的に作用する。この作用によ り芝生への薬害はない。

2 ）本㓮の作用機作は，スズメノカタビラの傷口 より侵入した本有効成分がスズメノカタビラ導管内 で増殖すると同時に，本有効成分の生産する粘性多 糖質であるキサンタンガムが導管を物理的に閉塞し, その結果としてスズメノカタビラが萎调，枯死する というものである。

3 ）本剂は生きた細菌からなるので遅効性であり, 効果の発現は季節による変動であるが, 散布後 1 か ら 3 r月かけて芝生中のスズメノカタビラの密度を 減少させる。この特性により, 密集したスズメノカ タビラの群落で用いても裸地化することなく自然に スズメノカタビラが芝草に遷移する。

\section{4 ）適用場面}

本剂はゴルフ場, 競技場, 公園等常時芝刈りの行 われる芝地で使用することができる。

\section{4.土壤中の動態}

圃場試験におけるザントモナス キャンペストリ スの半減期は約 0.5 日であり, 本剤が土壌中に残留す ることは，ほとんどないものと考えられる。

\section{5 . 植物体中での動龍}

本剂は, 葉, 根及び茎の傷口から吸収され, 導管 内を移行増殖していく。スズメノカタビラの 1 葉に 接種された場合, 接種葉より茎基部へ, 次いで根へ と順次移行して全身に感染する。

\section{6. 環境に対する影響}

1) 本㓮は，以下の環境生物に対して影響を及ほ さなかった。

水産動物（コイ，ミジンコ）

経済的に重要な植物

芝草及び牧草（ラフブルーグラスを除く）
ミツバチ
虫
天敵
土壤微生物 


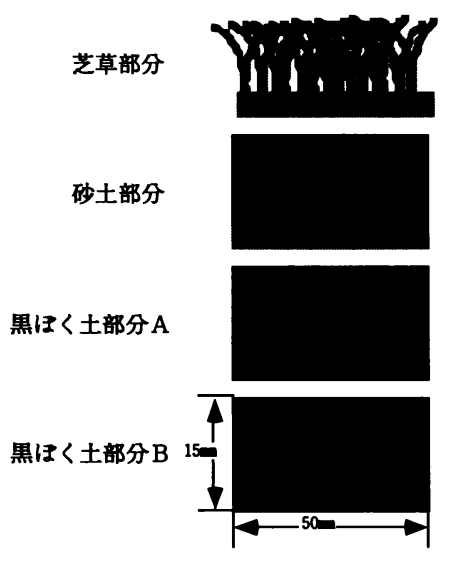

ソッド

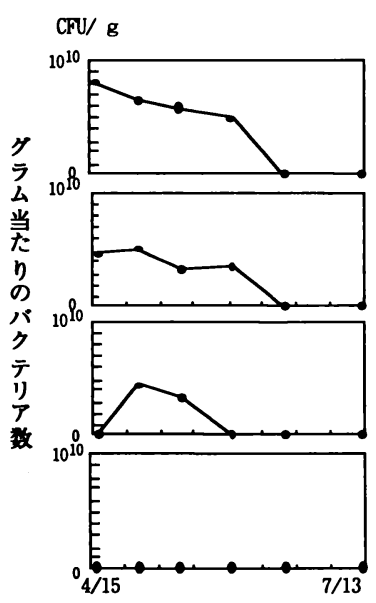

月/日

ベントクラス単独区

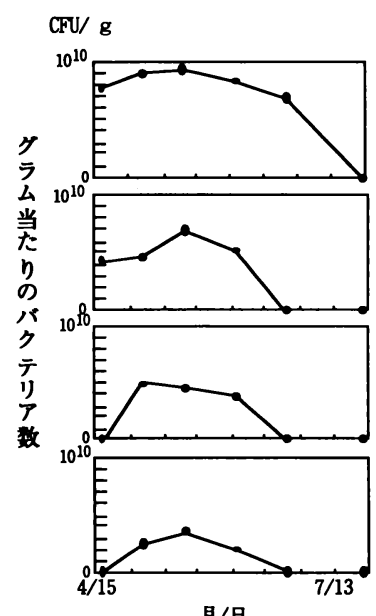

月/日

ススメノカタビラ植え込み区

図 1 散布後のバクテリア（ザントモナス キャンペストリス）数の変化

2 ）芝地における散布後の挙動を調查した結果, スズメノカタビラの有無に関わらず最終的にザント モナス キャンペストリスは, 検出限界以下になっ た。スズメノカタビラ植え込み区において，1 月月 目までザントモナス キャンペストリスは増加した が, 次第に減少し，3 月月後で検出限界以下に達し た。（図 1 ）これは 1 カ月目まで宿主であるスズメノ カタビラの導管内で増殖を続け，1 月月後にスズメ ノカタビラが枯死すると共に，ザントモナス キャ ンペストリスが減少したものと推察される。このこ とから，環境への影響は少ないと考えられる。

\section{7. 眉性}

1）急性毒性：普通物

表 1

\begin{tabular}{|c|c|c|}
\hline 投与経路 & 動物種 & $\begin{array}{c}\mathrm{LD}_{50} \text { 值又は } \\
\text { 最大無作用量 } \\
(\mathrm{CFU} / \mathrm{kg})\end{array}$ \\
\hline 経 口 & ラット & 盯우> $1.7 \times 10^{9}$ \\
\hline 経 皮 & ラット & 주욱 $7.8 \times 10^{8}$ \\
\hline 経気道 & ラット & 중우> $8.5 \times 10^{8}$ \\
\hline 静 脈 内 & ラット & 저우> $4.4 \times 10^{8}$ \\
\hline
\end{tabular}

2 ）魚毒性：

コイ及びミジンコに以下の濃度で暴露した場合, 全く影響を及ほさなかった。
コイ
$1.6 \times 10^{8} \mathrm{CFU} / \mathrm{ml}$
ミジンコ
$1.6 \times 10^{6} \mathrm{CFU} / \mathrm{ml}$

8. 登録年月日：平成 9 年 5 月 23 日

9. 本凨について参考となる文献

1 ）今泉誠子・波々伯部励・西野友規・小見川由美・ 山田昌雄 1994. 微生物除草剂によるスズメノカ タビラの防除. 雑草研究 39, (別) 40-41.

2) Imaizumi, S., T. Nishino, K. Miyabe, T. Fujimori and M. Yamada. 1997. Biol. Cont. 18, 714.

3 ) Imaizumi, S., A. Tateno and T. Fujimori. 1997. J. Weed Sci. Tech. 42, 8-17.

（日本たばこ産業(侏）西野順子） 
（脂肪酸系除草珮）

\section{P A}

\section{1 . 薬風の名称}

1) 一般名 : dalapon

2 ) 化学名:2,2-dichloropropionic acid sodium salt

3 ) 略名 : DPA-Na

4 ) 商品名：単剤は,「ダラポン水溶剤」「ダラポ ン粒剤」であり，本剤を含む混合剤 の主なものとして「クサブランカー 粒俼」「クサブランカー水和凨」など がある。

\section{2. 物理化学的性状}

1) 構造式
2 ）分子量： 164.95

3 ) 性状：類白色粉末

4 ) 融点 : $158.5^{\circ} \mathrm{C}$

5 ) 溶解度：水 $653 \mathrm{~g} / 1\left(25^{\circ} \mathrm{C}\right)$, メタノール 466 $\mathrm{g} / 1\left(25^{\circ} \mathrm{C}\right)$, エタノール $188 \mathrm{~g} / 1$ $\left(25^{\circ} \mathrm{C}\right)$ ，アセトン $5 \mathrm{~g} / 1\left(25^{\circ} \mathrm{C}\right)$

6 ) 蒸気圧 : 情報なし

\section{3 . 作用機構及び作用特性 ${ }^{12)}$}

非ホルモン型の除草剤でイネ科植物に対して選択 的な殺草作用を示す。浸透移行性が大きく，茎葉か ら吸収された本剤は師管を通って次第に下降し，根 に移行してパントテン酸の生成を阻害することによ り殺草力を発揮する。根からの吸収移行は茎葉ほど 速くない。茎葉からの吸収が主となるので, 土壤条 件による除草効果の差は少ない。除草効果の発現は, 茎葉に十分な除草効果が現れるまで 6 週間以上かか る場合もあるが，イネ科植物の生育後期に処理する ことにより翌年の萌芽を強力に抑制する。

作物に対する薬害は，イネ科作物に対する選択性 はないが，広葉植物は，種類によって異なり，ダイ ズ、ネギ類にはバイラス状萎縮を呈した薬害を示す。 土培中の移動は比較的大きく，除草効果持続期間 は20日ぐらいである。

\section{4 .土壤中の動態1)2)5}

DPA は,主として土壌中の微生物により速やかに 脱塩素化され, 脂肪酸代謝経路に入り $\mathrm{CO}_{2}$ まで分解 される。(図一1)

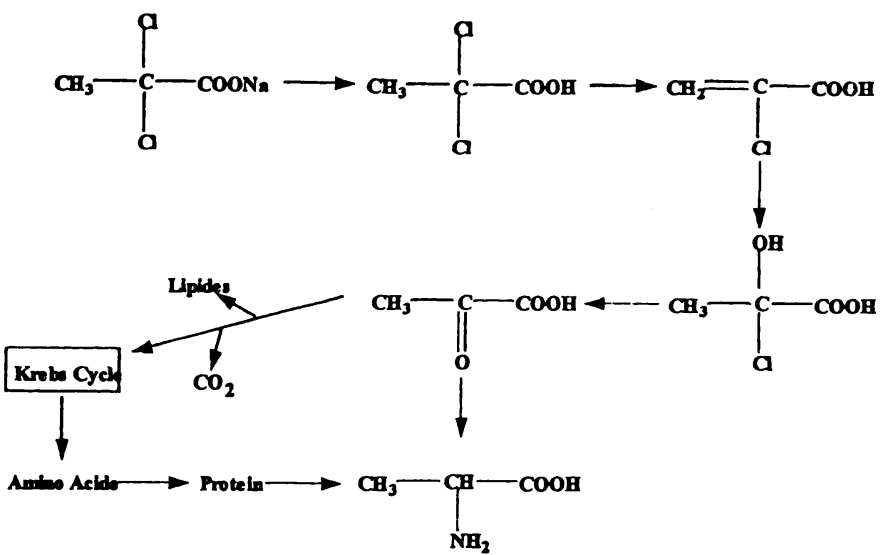

図一 1 土壤中における主要な代謝経路 ${ }^{2}$ 
DPA は,多くの土噇で 2 週間以内に分解されるが, 土㙋の性質により分解速度が異なり, 土壤中の水分, 温度が高いほどすみやかに分解が進む。

\section{5 . 植物体中の动態 ${ }^{3) 4}$}

ワタを用いた植物代謝試験では, DPA は遊離塩の 形で存在し，植物体内ではほとんど代謝されず全生 存期間を通し未変化のままで残留し,DPA が代謝さ れるということはなかった。

\section{6. 環境に対する影䈏1)}

水中において光分解, 微生物による分解などをう けて，比較的速やかに分解する。

\section{7 . 慧性}

1）急性毒性：普通物

\begin{tabular}{|c|c|c|}
\hline & & $\mathrm{LD}_{50}$ \\
\hline 経 口 & $\begin{array}{l}\text { ラット } \\
\text { マウ }\end{array}$ & $\begin{array}{l}\text { 『 우> } 5000 \mathrm{mg} / \mathrm{Kg} \\
\text { ఠ + ㄱ> } 5000 \mathrm{mg} / \mathrm{Kg}\end{array}$ \\
\hline 経 皮 & ラット & 省 우 $2000 \mathrm{mg} / \mathrm{Kg}$ \\
\hline
\end{tabular}

2 ）魚毒性：A類

\begin{tabular}{|c|c|c|c|c|}
\hline & & & & $\mathrm{LC}_{50}$ \\
\hline コ & & & 1 & $1000 \mathrm{mg} / 1$ \\
\hline$ミ$ & ジ & ン & $\exists$ & $1000 \mathrm{mg} / 1$ \\
\hline
\end{tabular}

3 ）覀急性毒性, 変異原性

亜急性毒性 経口毒性：ラット ○ $67.2 \mathrm{mg} / \mathrm{Kg} /$ 日 우 $77.6 \mathrm{mg} / \mathrm{Kg} /$ 日（最大 無作用量)
変異原性: Ames test, 染色体異常 試験ともに陰性

\section{8. 使用上の注意}

粘膜や皮成等に軽度の刺激性がある。 水田畦畔で使用する場合, 散布液がイネ体にかか ったり，本田に飛散流入しないように注意し，のり 面散布は避ける。

\section{9 . 登録年月日}

平成元年 5 月 25 日

\section{0. 引用文献}

1）農薬ハンドブック（1998年版）：pp.469 社日本植 物防疫協会

2 ) 除草片研究総覧：pp. 576-578 竹松哲夫 (博友 社)

3 ) F. A. Blanchard, W. W. Muelder, and G. N. Smith : Synthesis of carbon-14-labeled dalapon and trial applications to soybean and corn plants. J. Agr. Food Chem. 8, 124 (1960)

4 ) G. N. Smith, and D. L. Dyer: Fate of 2,2-dichloropropionic acide (delapon) in the cotton plant. J. Agr. food Chem. 9, 155 (1961)

5 ) B. E. Day, L. S. Jordan, and R. C. Russel : Persistence of dalapon residues in California soils. Soil Sci. 95, 326 (1963).

\section{（保土谷化学工業(侏) 安斎達雄）}


(環状イミド系除草咸)

\section{Pentoxazone}

\section{1. 薬凧の名称}

1) 一般名：ペントキサゾン

2 ) 化学名: 3-(4-chloro-5-cyclopentyloxy-2fluorophenyl) -5- isopropylidene -1,3- oxazolidine-2, 4-dione

3 ) 試験名 : KPP-314

4 ）商品名：単剤として「ベクサー」，本剤を含む 主な混合牏として「テマカット」,「ショキニー」

「草笛」などの初期剈,「ザ・ワン」,「スター ボ」「「ユートピア」,「草闘力」などの一発処 理剤がある。

\section{2. 物理化学的性状}

1) 構造式:<smiles>CC(C)=C1OC(=O)N(c2cc(OC3CCCC3)c(Cl)cc2F)C1=O</smiles>

2 ）分子量：353.78

3 ) 性 状：白色無臭の結晶性粉末

$4)$ 融 点: $104^{\circ} \mathrm{C}$

5 ) 溶解度：(g/ $\left.\ell, 25^{\circ} \mathrm{C}\right)$

$$
\begin{array}{lc}
\text { 水 } & 0.000216 \\
\text { メタノール } & 24.8 \\
\text { ヘキサン } & 5.10 \\
\text { イソプロピルアルコール } & 12.9 \\
\text { アセトン } & 100 \text { 以上 } \\
\text { エタノール } & 100 \text { 以上 } \\
\text { アセトニトリル } & 100 \text { 以上 } \\
\text { ジクロロメタン } & 100 \text { 以上 } \\
\text { 酢酸エチル } & 100 \text { 以上 }
\end{array}
$$

6 ) 蒸気圧： $1.11 \times 10^{-5} \mathrm{~Pa}$ 以下 $\left(25^{\circ} \mathrm{C}\right)$

\section{3．作用機構および作用特性}

1）本剤は発芽後の雑草幼芽部に対し特に強い殺 草作用を示す非ホルモン接触型・光要求性の
除草剤であり，その殺草作用は細胞構成成分 の光酸化的破壞に基づくものと考えられてい る。本剤は植物のクロロフィル生合成経路の うち，プロトポルフィリノーゲンオキシダー ゼを阻害する。結果的にプロトポルフィリン IXが蓄積し, 光存在下で活性酸素を発生させ, 細胞構成成分の酸化的な破壊をおこす。その 結果が細胞破壊を招き，ついには殺草活性が 発現するものと考えられている。

2 ) 本剤はノビエ, タマガヤツリ, コナギ, アゼ ナ等の水田一年生雑草全般およびマツバイに 高い除草効果を示す。また, 残効期間が長く, 雑草の発生を長期間にわたり抑制する。最近, 問題化しているスルホニルウレア系除草刘抵 抗性のアゼナ類やミズアオイ等にも有効であ ることが確認されている。本剤の使用時期は 雑草の発生前からノビエの 1 葉期までである が，雑草の幼芽部に特に強い殺草作用を示す ので, 雑草発生前の処理で最も高い除草効果 が期待できる。

3 ) 本剤は移植水稲に対し高い安全性を示す。極 端な深水条件下等で一過性の葉鞘褐変あるい は初期生育が発生する場合もあるが，その後 の回復は速やかであり，収量にまで影響する ことはないので，移植前および移植直後を含 む移植後のいずれの時期にも使用できる。

4 ) 本剤はその特長を生かし, 田植同時処理が可 能な長期残効型の一発処理剤として，また， 低薬量の単剤およびカヤツリグサ科雑草除草 剤と混合した初期㓮として各種薬郕が開発さ れており, 粒剤, フロアブル, 顆粒水和剤, ジャンボ剤などの戍型がある。

\section{4 . 土壤中の钦態}

1）土壤中の移動性

本剤の下方移動性は $1 \mathrm{~cm}$ 以下であり,小さい。

2 ）土壌中の半減期

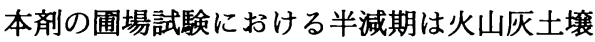
で23日（1 回処理）～40日（2 回処理）, 鉱質 土埪で 5 日（1 回処理） 10日 ( 2 回処理) である。

3 ）土壤中での代謝

${ }^{14} \mathrm{C}$ 標識ペントキサゾンを用いて土壤中におけ 
る挙動を検討した結果, 湛水条件での分解速 度は緩慢，畑条件では速やかであり，半減期 はそれぞれ10〜40週および 7 週であった。土 壤中では，主に土壤微生物による生物分解を 受け，最終的には $\mathrm{CO}_{2}$ まで分解されると考え られた。

\section{5. 植物体中の敦態}

1) 植物体での代謝

${ }^{14} \mathrm{C}$ 標識ペントキサゾンを移植水稲に処理した 結果，地上部への移行はほとんどみられず，収 穫期稲体中の放射能は玄米，茎葉部（わら），根 部でそれぞれ $0.046 ， 0.25 ， 0.23 \mathrm{ppm}$ であった。 一方, 稲体中における代謝分解は活発であり, 玄米中残留物の大部分は生体成分としての澱粉 に同化し，わら中でもセルロース，リグニンな どの生体成分として存在した。

2 ）作物残留性

安全性評価および作物残留試験結果に基づき, 本剤の残留農薬基準が米0.1ppm に設定された (平成11年11月 22 日付厚生省告示)。

\section{6.環境に対する影䈏}

本剂は水溶解度が極めて小さく, 土壌吸着性が比 較的大きいため，河川への流亡が少なく，環境に対 する安全性は高いと考えられる。また，鳥類および カイコ, ミツバチ, クモ類, ミミズなどの有用昆虫 などに対する影響試験の結果，通常の使用で影響を 及浑す可能性は低いと考えられる。

\section{7. 繁性}

1) 急性毒性：普通物相当

\begin{tabular}{|c|c|c|}
\hline 投与経路 & 動物種等 & $\mathrm{LD}_{50}$ \\
\hline \multirow[t]{2}{*}{ 経口 } & ラット（の゚+ & $>5000 \mathrm{mg} / \mathrm{kg}$ \\
\hline & マウス (の゚ 古) & $>5000 \mathrm{mg} / \mathrm{kg}$ \\
\hline 経皮 & ラット(の゚ & $>2000 \mathrm{mg} / \mathrm{kg}$ \\
\hline 吸入 & ラット (の+゚) & $>5100 \mathrm{mg} / \mathrm{m}^{3}$ \\
\hline
\end{tabular}

2 ）魚毒性：B 類相当

\begin{tabular}{|c|c|}
\hline 供試生物 & $\mathrm{LC}_{50}$ (ppm) \\
\hline ב & 22 (96時間) \\
\hline 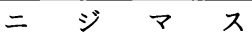 & $>40$ (96時間) \\
\hline セスジミジンコ & $>100$ (24時間) \\
\hline
\end{tabular}

3 ）亜急性, 慢性毒性等

\begin{tabular}{|c|c|c|}
\hline 試験名 & 動物種等 & 無毒性量（mg/kg/日） \\
\hline 亜急性 & $\begin{array}{lll}\text { ラ } & \text { ト } \\
\text { マ } & \text { ス } \\
\text { イ } & \text { ヌ }\end{array}$ & 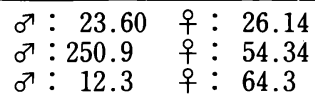 \\
\hline $\begin{array}{l}\text { 慢性毒性 } \\
\text { /発癌性 } \\
\text { 発癌性慢性 }\end{array}$ & $\begin{array}{lll}\text { ラ } & \text { ト } \\
& & \\
\text { マ } & \text { オ } \\
\text { イ } & & \text { ヌ }\end{array}$ & 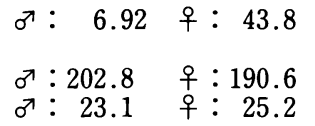 \\
\hline 繁殖性 & ラット & 影響なし \\
\hline 催奇形性 & $\begin{array}{l}\text { ラット } \\
\text { ウサギ }\end{array}$ & $\begin{array}{l}\text { なし } \\
\text { なし }\end{array}$ \\
\hline 復㷌変異性 & 細 菌 & 陰性 \\
\hline 染色体異常 & 動物細胞 & -S9で陰性, +S9で陽性 \\
\hline DNA 修復 & 枯草菌 & 陰性 \\
\hline 小核試験 & マウ ス & 陰性 \\
\hline
\end{tabular}

8. 登録年月日

平成 9 年12月 22 日

\section{9. 本剤について参考となる文献}

1) 鵜飼貞行ほか 1992.日本農薬学会第17回大会講 演要旨, 47.

2 ）吉村友喜ほか 1992．日本農薬学会第17回大会講 演要旨, 48 .

3 ）植田拓也ほか 1995. 雑草研究40(別)，150-151

4）植田拓也ほか 1996. 雑草研究41 (別)，10-11

5 ）植田拓也ほか 1999. 雑草研究44(別)，304-305

6 ) Kenji HIRAI. et al., 1999. 日本農薬学会誌24 (2) , 156-169 